\title{
Single-walled carbon nanotube growth at low temperature by alcohol gas source method using Co catalyst: enhancement effects of $\mathrm{Al}_{2} \mathrm{O}_{3}$ buffer layer on carbon nanotube yield
}

\author{
Takuya Okada ${ }^{1}$, Takahiro Saida ${ }^{1,2}$, Shigeya Naritsuka ${ }^{3}$, Katsutoshi Fukuda $^{4}$ \\ and Takahiro Maruyama ${ }^{1,2^{*}}$ \\ 1 Department of Applied Chemistry, Meijo University, Nagoya 468-8502, Japan \\ 2 Nanomaterials Research Center, Meijo University, Nagoya 468-8502, Japan \\ 3 Department of Materials Science and Engineering, Meijo University, Nagoya 468-8502, Japan \\ 4 Office of Society-Academia Collaboration for Innovation, Kyoto University, Kyoto 606-8501, Japan \\ * Corresponding author: Fax: 81-52-832-1179, and e-mail: takamaru@meijo-u.ac.jp
}

\begin{abstract}
Using an alcohol gas source chemical vapor deposition method, we attempted to grow single-walled carbon nanotube (SWCNT) growth using Co catalysts on $\mathrm{Al}_{2} \mathrm{O}_{3}$ buffer layers. Reducing the growth temperature decreased the optimal ethanol pressure to obtain the highest SWCNT yield. By optimizing the ethanol pressure, we succeeded in growing SWCNTs at $400^{\circ} \mathrm{C}$. Irrespective of the growth temperature, SWCNT yields from Co catalysts on $\mathrm{Al}_{2} \mathrm{O}_{3}$ buffer layers were higher than those on $\mathrm{SiO}_{2} / \mathrm{Si}$ substrates, but the enhancing effects of $\mathrm{Al}_{2} \mathrm{O}_{3}$ buffer layers on SWCNT yield were reduced below $500^{\circ} \mathrm{C}$. Taking into account both in-plane X-ray diffraction results and decrease of catalyst aggregation in the low temperature region, we concluded that the density of Co particles suitable for SWCNT growth increased on $\mathrm{SiO}_{2}$ surface at low temperature, resulting in the reduction of difference in SWCNT yield at low temperature between $\mathrm{Al}_{2} \mathrm{O}_{3}$ buffer layers and $\mathrm{SiO}_{2} / \mathrm{Si}$ substrates.

Key words: single-walled carbon nanotube, CVD, catalyst, Co, low-temperature growth
\end{abstract}

\section{INTRODUCTION}

Since a discovery by Iijima, ${ }^{1}$ single-walled carbon nanotubes (SWCNTs) have attracted much attention due to their remarkable properties such as ballistic transport, ${ }^{2}$ high mobility, ${ }^{3}$ and high current carrying density. ${ }^{4}$ Therefore, they offer huge potential for electronics applications such as field effect transistors (FETs), ${ }^{5,6}$ LSI interconnects, ${ }^{7,8}$ and energy conversion devices. ${ }^{9,10}$ To realize SWCNT devices compatible with LSI manufacturing processes, SWCNT synthesis below $400^{\circ} \mathrm{C}$ is essential to avoid degradation of interlayer dielectric films during SWCNT growth. So far, several groups have reported SWCNT growth at low temperatures. ${ }^{12-14}$ However, only a few studies have been reported for SWCNT growth below $500^{\circ} \mathrm{C}$ using Co catalysts, although Co has been widely used in catalysts for SWCNT growth by alcohol catalytic CVD (ACCVD) ${ }^{15-20}$ In particular, low-temperature growth of SWCNTs using Co catalysts on $\mathrm{Al}_{2} \mathrm{O}_{3}$ buffer layers has scarcely been performed, even though $\mathrm{Al}_{2} \mathrm{O}_{3}$ buffer layers are recognized to enhance the SWCNT yield in CVD and metal catalysts are frequently supported on $\mathrm{Al}_{2} \mathrm{O}_{3}$ buffer layers. ${ }^{13,14,21-24}$

In general, it is recognized that metal particles that are a few nanometers (typically $1-3 \mathrm{~nm}$ ) in diameter act as effective catalysts for SWCNT growth. ${ }^{25}$ Compared to $\mathrm{SiO}_{2} / \mathrm{Si}$ substrates, aggregation of catalyst particles is suppressed on $\mathrm{Al}_{2} \mathrm{O}_{3}$ buffer layers, ${ }^{26-28}$ and the number of catalyst particles whose sizes are suitable for SWCNT growth increases. However, surface migration distance of catalyst metals should decrease with the reduction of growth temperature, thus, there is a possibility that
$\mathrm{Al}_{2} \mathrm{O}_{3}$ buffer layers do not enhance SWCNT yield in low-temperature growth, although the increase of SWCNT yield at low temperature is a significant issue for realization of SWCNTs electronic devices.

In this study, we report SWCNT growth at low temperature by an alcohol gas source method using Co catalysts on $\mathrm{Al}_{2} \mathrm{O}_{3}$ buffer layers. We compared SWCNT yields on $\mathrm{Al}_{2} \mathrm{O}_{3}$ buffer layers with those on $\mathrm{SiO}_{2} / \mathrm{Si}$ substrates and investigated temperature dependence of the enhancement effect of an $\mathrm{Al}_{2} \mathrm{O}_{3}$ buffer layer on SWCNT yield. Additionally, we characterized $\mathrm{Al}_{2} \mathrm{O}_{3}$ buffer layers by in-plane X-ray diffraction (XRD), and showed that crystallinity of $\mathrm{Al}_{2} \mathrm{O}_{3}$ buffer layers did not change remarkably between 400 and $700^{\circ} \mathrm{C}$. Based on these results, we discussed the effect of an $\mathrm{Al}_{2} \mathrm{O}_{3}$ buffer layer on SWCNT growth at low temperature.

\section{EXPERIMENTAL METHOD}

$\mathrm{Co}$ catalysts were deposited on $\mathrm{Al}_{2} \mathrm{O}_{3} / \mathrm{SiO}_{2} / \mathrm{Si}$ substrates using electron beam deposition in an ultrahigh vacuum (UHV) chamber. $\mathrm{Al}_{2} \mathrm{O}_{3}$ buffer layers were formed by depositing $\mathrm{Al}$ on $\mathrm{SiO}_{2} / \mathrm{Si}$ substrates by rf-sputtering, followed by exposure to air to allow oxidation. The Co and Al thicknesses were 0.2 and 20 $\mathrm{nm}$, respectively; these were monitored with a quartz crystal oscillator. SWCNT growth was performed in a UHV chamber equipped with a stainless steel nozzle for introducing ethanol gas, that is, "gas source type ACCVD." Details of the setup are given in our previous studies. ${ }^{29-31}$ The base pressure of this system was below $1 \times 10^{-6} \mathrm{~Pa}$. The ethanol pressure was controlled with a variable leak valve and monitored by a vacuum ion 
gauge, which allowed a minute gas supply and precise control of the ethanol pressure to achieve optimum growth conditions. For SWCNT growth, ethanol gas was supplied directly to the substrate surface for $1 \mathrm{~h}$ through the nozzle. The substrate temperature was monitored with a pyrometer (KTL-Pro, LEC Ltd. Tokyo, Japan). The morphology of the grown SWCNTs was characterized using field-emission scanning electron microscopy (FESEM) (JSM-6700F, JEOL, Tokyo, Japan). The accelerating voltage used for SEM observation was $5 \mathrm{kV}$. Raman spectra of the samples were obtained using a Raman system (RAMANforce, Nanophoton, Osaka, Japan) to evaluate the diameter and chirality of the as-grown SWCNTs. The excitation wavelength used for Raman measurements was $671 \mathrm{~nm}$. $\mathrm{Al}_{2} \mathrm{O}_{3}$ buffer layers were characterized by in-plane XRD, which was performed at beamline BL6C of the Photon Factory at the High Energy Accelerator Research Organization (KEK) using synchrotron $\mathrm{X}$-ray radiation $(\lambda=0.12011 \mathrm{~nm})$ and energy dispersive X-ray spectrometry (EDX) (EMAX, Horiba, Kyoto, Japan).

\section{RESULTS AND DISCUSSION}

Figure 1(a) and (b) shows SEM images for samples grown at $500^{\circ} \mathrm{C}$ and $400^{\circ} \mathrm{C}$, respectively. The ethanol pressures used to grow these samples were $1 \times 10^{-3}$ and $1 \times 10^{-4} \mathrm{~Pa}$, respectively; these were optimized for each growth temperature to obtain the highest product yield. Fibrous products were observed on both substrate surfaces, which exhibited web-like structures. Longer fibers were formed at $500^{\circ} \mathrm{C}$ than at $400^{\circ} \mathrm{C}$.
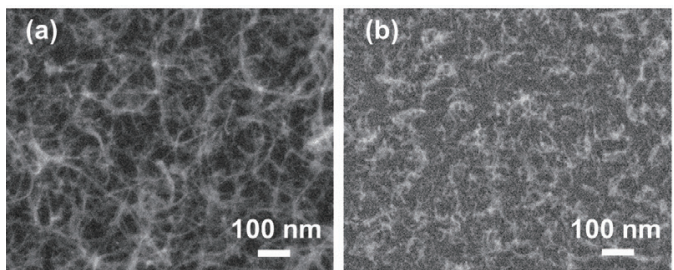

Fig. 1. SEM images of SWCNTs grown with Co catalysts on $\mathrm{Al}_{2} \mathrm{O}_{3} / \mathrm{SiO}_{2} / \mathrm{Si}$ substrates at (a) $500^{\circ} \mathrm{C}$ at an ethanol pressure of $1 \times 10^{-3} \mathrm{~Pa}$ and (b) $400^{\circ} \mathrm{C}$ at 1 $\times 10^{-4} \mathrm{~Pa}$.

Figure 2(a) and (b) shows Raman spectra of these samples, measured using an excitation wavelength of $671 \mathrm{~nm}$. These spectra showed both $\mathrm{G}$ bands at 1594 $\mathrm{cm}^{-1}$ and radial breathing mode (RBM) peaks, indicating that SWCNTs were grown under these conditions. In addition, strong RBM peaks were observed at 167 and $176 \mathrm{~cm}^{-1}$ for the samples grown at $500^{\circ} \mathrm{C}$ and $400^{\circ} \mathrm{C}$, respectively, that is, the fibrous products shown in Fig. 1 were confirmed as SWCNTs. Considering the relationship between the SWCNT diameter, $d$, and the wavenumber of its RBM peak, $\omega, d[\mathrm{~nm}]=$ $248 / \omega\left[\mathrm{cm}^{-1}\right], 32$ some of grown SWCNTs have diameters between 1.40 and $1.49 \mathrm{~nm}$. The G/D ratio of SWCNTs grown at $500^{\circ} \mathrm{C}$ was 11.2 , while that for those grown at $400^{\circ} \mathrm{C}$ was about 3.6 . This indicates that the crystallinity of SWCNTs deteriorated as the growth temperature was reduced.

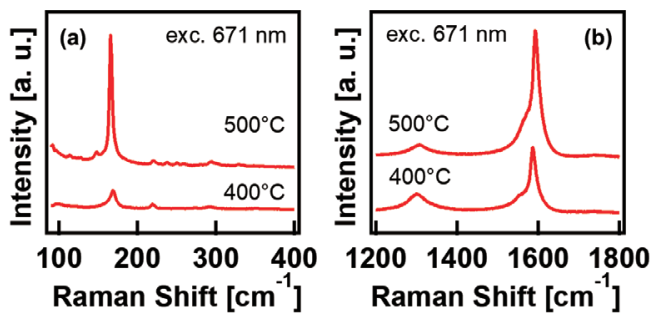

Fig. 2. (a) Raman spectra in the RBM region and (b) Raman spectra in the high energy region for SWCNTs grown with Co catalysts on $\mathrm{Al}_{2} \mathrm{O}_{3} / \mathrm{SiO}_{2} / \mathrm{Si}$ substrates at $400^{\circ} \mathrm{C}$ and $500^{\circ} \mathrm{C}$ at the optimal ethanol pressures.

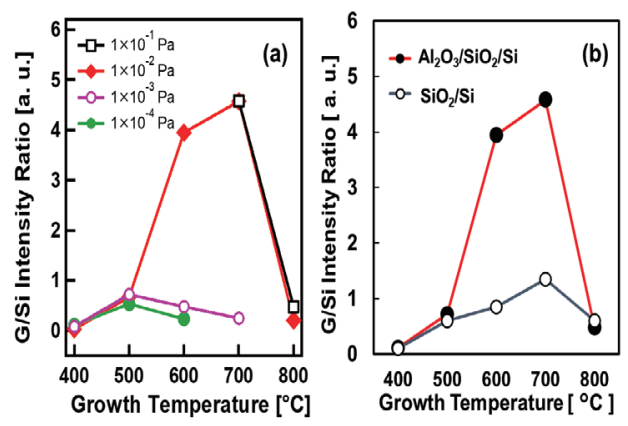

Fig. 3. (a) Relationship between the growth temperature and the $\mathrm{G} / \mathrm{Si}$ intensity ratio for each ethanol pressure for SWCNT growth with Co catalysts on $\mathrm{Al}_{2} \mathrm{O}_{3} / \mathrm{SiO}_{2} / \mathrm{Si}$ substrates. (b) The relationship between the $\mathrm{G} / \mathrm{Si}$ intensity ratio and the growth temperature for SWCNTs grown with Co catalysts on $\mathrm{Al}_{2} \mathrm{O}_{3} / \mathrm{SiO}_{2} / \mathrm{Si}$ and $\mathrm{SiO}_{2} / \mathrm{Si}$ substrates at the optimal ethanol pressures.

Considering the morphology of the grown SWCNTs, the intensity ratios of the $\mathrm{G}$ bands relative to the $\mathrm{Si}$ peak $^{33}$ at $\sim 520 \mathrm{~cm}^{-1}(\mathrm{G} / \mathrm{Si}$ ratio) roughly correspond to the SWCNT yields. To evaluate the dependence of the SWCNT yield on the growth conditions, we performed Raman measurements of the samples grown under various conditions using a laser with an excitation wavelength of $671 \mathrm{~nm}$. Fig. 3(a) shows the growth temperature dependence of the $\mathrm{G} / \mathrm{Si}$ ratio, which is shown for each ethanol pressure. At a growth temperature of $700^{\circ} \mathrm{C}$, the SWCNT yield (G/Si ratio) reached a maximum at ethanol pressures of $1 \times 10^{-1}$ and $1 \times 10^{-2} \mathrm{~Pa}$. However, at a growth temperature of $500^{\circ} \mathrm{C}$, it peaked at an ethanol pressure of $1 \times 10^{-3} \mathrm{~Pa}$. At $400^{\circ} \mathrm{C}$, the SWCNT yield reached a maximum at ethanol pressures of $1 \times 10^{-3}$ and $1 \times 10^{-4} \mathrm{~Pa}$. A decrease in the optimal ethanol pressure with a reduction in the SWCNT growth temperature was reported for various metal catalysts. ${ }^{14,29,34}$ This could be due to a reduction in the dissociation rate of carbon feedstock molecules on catalyst particles with a decrease in growth temperature, confirming that optimization of the feedstock gas flow is important for low temperature synthesis of SWCNTs. Fig. 3(a) shows that the SWCNT yield reached a maximum at $700^{\circ} \mathrm{C}$ under the optimal ethanol pressure, 
indicating that $700^{\circ} \mathrm{C}$ was the optimal growth temperature for obtaining the highest yield. Below $500^{\circ} \mathrm{C}$, the SWCNT yield was drastically reduced, which is probably due to reduction of catalyst activity at low temperature.

We also investigated the effect of the $\mathrm{Al}_{2} \mathrm{O}_{3}$ buffer layers on the catalyst activity. Fig. 3(b) shows the G/Si ratios for SWCNTs grown with Co catalysts on $\mathrm{Al}_{2} \mathrm{O}_{3}$ buffer layers and $\mathrm{SiO}_{2} / \mathrm{Si}$ substrates at the optimal ethanol pressures. The data for SWCNTs on $\mathrm{SiO}_{2} / \mathrm{Si}$ substrates were taken from our previous study. ${ }^{19}$ At growth temperatures between $600^{\circ} \mathrm{C}$ and $700^{\circ} \mathrm{C}$, the $\mathrm{G} / \mathrm{S}$ ratios for SWCNTs on $\mathrm{Al}_{2} \mathrm{O}_{3}$ buffer layers were much higher than those on $\mathrm{SiO}_{2} / \mathrm{Si}$ substrates. However, the difference in the $\mathrm{G} / \mathrm{Si}$ ratios was small, when the growth temperature was below $500^{\circ} \mathrm{C}$ and above $800^{\circ} \mathrm{C}$. Considering that transmittance of 600-700 nm-light for the $20 \mathrm{~nm}-\mathrm{Al}_{2} \mathrm{O}_{3}$ buffer layers were $98-99 \%,{ }^{36}$ the reduction of $\mathrm{Si}$ peaks due to $\mathrm{Al}_{2} \mathrm{O}_{3}$ buffer layers should be negligible in Raman spectra. Therefore, this result indicates that SWCNT yields on $\mathrm{Al}_{2} \mathrm{O}_{3}$ buffer layers were higher than those on $\mathrm{SiO}_{2} / \mathrm{Si}$ substrates, but the enhancement effect of $\mathrm{Al}_{2} \mathrm{O}_{3}$ buffer layers on SWCNT growth was reduced below $500^{\circ} \mathrm{C}$ and above $800^{\circ} \mathrm{C}$.

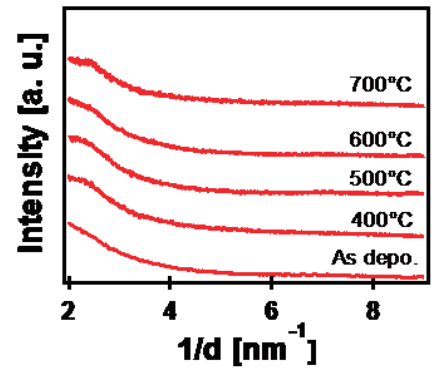

Fig. 4. In-plane $\mathrm{XRD}$ pattern for an $\mathrm{Al}_{2} \mathrm{O}_{3}$ buffer layer and those after annealing at 400, 500, 600 and $700^{\circ} \mathrm{C}$ in a vacuum.

To investigate the reduction in the enhancement effect below $500^{\circ} \mathrm{C}$, we performed in-plane XRD measurements on $\mathrm{Al}_{2} \mathrm{O}_{3}$ buffer layers. Fig. 4 shows an in-plane XRD pattern of an $\mathrm{Al}_{2} \mathrm{O}_{3}$ buffer layer and those annealed between 400 and $700^{\circ} \mathrm{C}$ in a vacuum. After annealing, only one broad peak was seen at around 2.5 $\mathrm{nm}^{-1}$, which might be derived from $\gamma-\mathrm{AlO}(\mathrm{OH}),{ }^{36}$ and no distinct peaks corresponding to $\alpha$ - or $\gamma-\mathrm{Al}_{2} \mathrm{O}_{3}{ }^{37}$ were observed. This indicates that the $\mathrm{Al}_{2} \mathrm{O}_{3}$ buffer layer used for SWCNT growth at $400^{\circ} \mathrm{C}$ was amorphous. Amama et al. reported the influence of the alumina type on the activity of $\mathrm{Fe}$ catalyst particles for SWCNT growth at $750^{\circ} \mathrm{C}$ and showed that amorphous $\mathrm{Al}_{2} \mathrm{O}_{3}$ was more effective, because aggregation of $\mathrm{Fe}$ catalysts was suppressed on amorphous $\mathrm{Al}_{2} \mathrm{O}_{3}$ buffer layers. ${ }^{38}$ In our experiment, the enhancement effect of $\mathrm{Al}_{2} \mathrm{O}_{3}$ buffer layer on SWCNT yield was small below $500^{\circ} \mathrm{C}$, even though the $\mathrm{Al}_{2} \mathrm{O}_{3}$ buffer layer was amorphous. It is generally recognized that $\mathrm{Al}_{2} \mathrm{O}_{3}$ buffer layers suppress aggregation of catalyst particles. ${ }^{26-28}$ However, in the low temperature region, aggregation of Co catalysts should be reduced even on $\mathrm{SiO}_{2} / \mathrm{Si}$ substrates. Consequently, the enhancement effect of the $\mathrm{Al}_{2} \mathrm{O}_{3}$ buffer layer on the SWCNT yield was remarkably reduced below $500^{\circ} \mathrm{C}$. At a growth temperature of $800^{\circ} \mathrm{C}$, the $\mathrm{G} / \mathrm{Si}$ ratios for the $\mathrm{Al}_{2} \mathrm{O}_{3}$ buffer layer and the $\mathrm{SiO}_{2} / \mathrm{Si}$ substrate were also similar. This might be due to the inward diffusion of the Co catalyst on the $\mathrm{Al}_{2} \mathrm{O}_{3}$ buffer layer at high temperatures, ${ }^{39}$ which reduced the amount of Co catalyst on the substrate surface.

We also report high-density growth of SWCNTs at low temperatures. At growth temperatures below $500^{\circ} \mathrm{C}$, areas of high-density SWCNT growth were observed on some portions of the $\mathrm{Al}_{2} \mathrm{O}_{3}$ buffer layer, as shown in Fig. 5(a) and (b), where SWCNTs were grown vertically with a high density. These high-density growth was observed for samples grown under the optimal ethanol pressure, when the growth temperature was 400 and $500^{\circ} \mathrm{C}$. The size of each growth area was about several $\mu \mathrm{m}$, and their density was about $100 / \mathrm{mm}^{2}$, when the growth temperature was $500^{\circ} \mathrm{C}$. Although the density decreased drastically at $400^{\circ} \mathrm{C}$, these high-density growth was still observed. Considering the fact that such a high-density growth was not observed with Co catalysts on $\mathrm{SiO}_{2} / \mathrm{Si}$ substrates, local variations of surface structures in the $\mathrm{Al}_{2} \mathrm{O}_{3}$ buffer layer might have affected the activity of the Co catalysts, although the mechanism of the high-density growth is currently unclear. By clarifying this mechanism, high-density growth of SWCNTs could be realized at low temperatures.
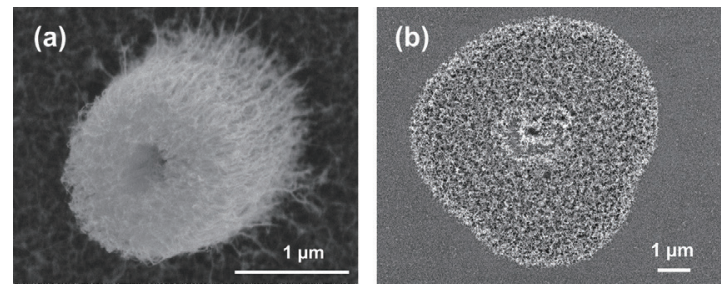

Fig. 5. Area of high-density growth of SWCNTs grown with Co catalysts on $\mathrm{Al}_{2} \mathrm{O}_{3} / \mathrm{SiO}_{2} / \mathrm{Si}$ substrates at (a) $400^{\circ} \mathrm{C}$ under an ethanol pressure of $1 \times 10^{-4} \mathrm{~Pa}$ and (b) $500^{\circ} \mathrm{C}$ under an ethanol pressure of $1 \times 10^{-3}$ $\mathrm{Pa}$.

\section{CONCLUSION}

We achieved SWCNT growth by an alcohol gas source method using Co catalysts on $\mathrm{Al}_{2} \mathrm{O}_{3}$ buffer layers and obtained web-like SWCNTs even at $400^{\circ} \mathrm{C}$. However, the enhancement of the SWCNT yield by the $\mathrm{Al}_{2} \mathrm{O}_{3}$ buffer layers was reduced below $500^{\circ} \mathrm{C}$. In-plane XRD showed that the $\mathrm{Al}_{2} \mathrm{O}_{3}$ buffer layer was amorphous at $400^{\circ} \mathrm{C}$. This indicates that aggregation of Co catalysts was decreased on $\mathrm{SiO}_{2} / \mathrm{Si}$ substrates below $500^{\circ} \mathrm{C}$, resulting in reduced enhancement of the SWCNT yield on the $\mathrm{Al}_{2} \mathrm{O}_{3}$ buffer layers.

\section{ACKNOWLEDGMENTS}

This work was supported in part by Private University Research Branding Project from the Ministry of Education, Culture, Sports, Science and Technology (MEXT), Japan. Part of this work was conducted at the Institute for Molecular Science (IMS), supported by the "Nanotechnology Platform" of the Ministry of Education, Culture, Sports, Science and Technology (MEXT), Japan. 


\section{REFERENCES}

[1] S. Iijima and T. Ichihashi, Nature 363, 603 (1993).

[2] A. Javey, J. Guo, Q. Wang, M. Lundstrom and H. Dai, Nature 424, 654 (2003).

[3] T. Dürkop, S. A. Getty, E. Cobas and M. S. Fuhrer, Nano Lett. 4, 35-39 (2004).

[4] S. Hong and S. Myung, Nature Nanotech. 2, 207 (2007).

[5] S. J. Tans, A. R. M. Vershueren and C. Dekker, Nature 393, 49 (1998).

[6] S. J. Wind, J. Appenzeller, R. Martel, V. Derycke and P. Abouris, Appl. Phys. Lett. 80, 3817 (2002).

[7] D. Kondo, S. Sato, A. Kawabata and Y. Awano, Nanotechnol. 19, 435601 (2008).

[8] T. Iwasaki, J. Robertson and H. Kawarada, Nano Lett. 8, 886 (2008).

[9] G. Girishkumar, K. Vinodgopal and P. V. Kamat, J. Phys. Chem. B 10819960 (2004).

[10] M. W. Rowell, M. A. Topinka, M. D. McGehee, H.-J. Prall, G. Dennler, N. S. Sariciftci, L. Hu and G. Gruner, Appl. Phys. Lett. 88, 233506 (2006).

[11] M. He, A. I. Chemov, E. D. Obraztsova, J. Sainio, E. Rikkinen, H. Jiang, Z. Zhu, A. Kaskela, A. G. Nasibulin, E. I. Kauppinen, M. Niemelä and O. Krause, Nano Res. 4, 334 (2011).

[12] E. J. Bae, Y. S. Min, D. Kang, J. H. Ko and W. Park, Chem. Mater. 17, 5141 (2005).

[13] M. Cantoro, S. Hofmann, S. Pisana, V. Scardaci, A. Parvez, C. Ducati, A. C. Ferrari, A. M. Blackburn, K. Y. Wang and J. Robertson, Nano Lett. 6, 1107 (2006).

[14] T. Maruyama, A. Kozawa, T. Saida, S. Naritsuka and S. Iijima, Carbon 116, 128 (2017).

[15] S. Maruyama, R. Kojima, Y. Miyauchi, S. Chiashi and K. Kouhno, Chem. Phys. Lett. 360, 229 (2002).

[16] M. Fouquet, B. C. Bayer, S. Esconjauregui, R. Blume, J. H. Warner, S. Hofmann, R. Schlöl, S Thomsen and J. Robertson, Phys. Rev. B 85, 235411 (2002).

[17] S. M. Bachilo, L. Balzano, J. E. Herrera, F. Pompero, D. E. Resasco and R. B. Weisman, J. Am. Chem. Soc. 125, 11186 (2003).

[18] Y. Ishikawa and K. Ishizuka, Appl. Phys. Express 2, 045001(2009).

[19] K. Tanioku, T. Maruyama and S. Naritsuka, Diamond Relat. Mater. 17, 589 (2008).

[20] T. Maruyama, K. Sato, Y. Muzutani, K. Tanioku, T. Shiraiwa and S. Naritsuka, J. Nanosci. Nanotechnol. 10, 4095 (2010).

[21] K. Hata, D. N. Futaba, K. Mizuno, T. Namai, M. Yumura and S. Iijima, Science 306, 1362 (2004).

[22] S. Noda, K. Hasegawa, H. Sugime, K. Kakechi, Z. Zhang, S. Maruyama and Y. Yamaguchi, Jpn. J. Appl. Phys. 46, L399 (2007).

[23] H. Zhang, G. Cao, Z. Wang, Y. Yang, Z. Shi and Z. Gu, J. Phys. Chem. C 112, 4524 (2008).

[24] P. B. Amama, C. L. Pint, F. Mirri, M. Pasquali, R. H. Hauge and B. Maruyama, Carbon 50, 2396 (2012).

[25] T. Maruyama, Mater. Express 8, 1 (2018).

[26] H. Ohno, D. Takagi, K. Yamada, S. Chiashi, A. Tokura and Y. Homma, Jpn. J. Appl. Phys. 47, 1956 (2008).

[27] A. Kaneko, K. Yamada, R. Kumahara, H. Kato and Y. Homma, J. Phys. Chem. C 116, 26060 (2012).
[28] C. Mattive, C. T. Wirth, S. Hofmann, R. Blume, M. Cantoro, C. Ducati, C. Cepek, A. Knop-Gericke, S. Milne, C. Castellarin-Cudia, S. Dolafi, A. Goldoni, R. Schlogel and J. Robertson, J. Phys. Chem. C 112, 12207 (2008).

[29] T. Maruyama, H. Kondo, R. Ghosh, A. Kozawa, S Naritsuka, Y. Iizumi, T. Okazaki and S. Iijima, Carbon 96, 6 (2016).

[30] A. Kozawa, H. Kiribayashi, S. Ogawa, T. Saida, S. Naritsuka and T. Maruyama, Diamond Relat. Mater. 63, 159 (2016).

[31] T. Fujii, H. Kiribayashi, T. Saida, S. Naritsuka and T. Maruyama, Diamond Relat. Mater. 77, 159 (2017).

[32] A. Jorio, R. Saito, J. H. Hafner, C. M. Liever, M. Hunter, T. McClure, G. Dresselhaus and M. S. Dresselhaus, Phys. Rev. B 86, 1118 (2001).

[33] J. H. Parker, Jr,, D. W. Feldman and M. Ashkin, Phys. Rev. 155, 712 (1967).

[34] M. Picher, E. Anglaret, R. Arenal and V. Jourdain, ACS Nano 5, 2118 (2011).

[35] N. Avci, J. Musschoot, P. F. Smet, K. Korthout, A. Avci, C. Detavernier and D. Poelman, J. Electrochem. Soc. 156, J333 (2009).

[36] Y. Liu, D. Ma, X. Han, X. Bao, W. Frandsen, D. Wang and D. Su, Mater. Lett. 62, 1297 (2008).

[37] T. S. Shih and Z. B. Liu, Mater. Trans. 47, 1347 (2006).

[38] P. B. Amama, C. L. Pint, S. M. Kim, L. McJilton, K. G. Eyink, E. A. Stach, R. H. Hauge and B. Maruyama, ACS Nano 4, 895 (2010).

[39] K. Sato, T. Shiraiwa, T. Maruyama and S. Naritsuka, J. Nanosci. Nanotechnol. 10, 3929 (2010).

(Received November 9, 2018; Accepted February 4, 2019; Published Online April 1, 2019) 